Behnia (2021)

\title{
ANSERJ
}

Vol. 12, No. 1

Spring / printemps 2021

pp. $23-37$

Canadian Journal of Nonprofit and Social Economy Research

Revue canadienne de recherche sur les OSBL et l'économie sociale

\section{Role Commitment and Role Maintenance Strategies: A Symbolic Interactionist Approach to Volunteering}

\author{
Behnam Behnia \\ Carleton University
}

\begin{abstract}
There are numerous reports on the rates of attrition among volunteers as a persistent challenge for organizations. In explaining volunteer attrition, researchers have predominantly: 1) provided an individualistic account of volunteering; 2) overlooked the interactional dimension of volunteer work and the crucial role of interpretation in its development; and 3) assumed commitment as a function of satisfaction with volunteering experience. Drawing on the theoretical insights of a symbolic interactionist approach, this article contends that volunteers' role commitment hinges on their satisfaction with their interpretation of their interaction with clients, rather than the interaction itself. This perspective calls attention to the volunteer-client dyadic interaction, gives a prominent place to the social role and its definition, and draws attention to strategies used by volunteers to sustain challenging relationship with clients.
\end{abstract}

\section{RÉSUMÉ}

II existe de nombreux rapports sur les pourcentages de bénévoles perdus et le défi que ces pertes posent pour les organismes. Pour expliquer ces bénévoles perdus, les chercheurs ont surtout : 1) fourni des comptes rendus individualistes du bénévolat; 2) ignoré la dimension interactionnelle du bénévolat et le rôle crucial de l'interprétation dans le développement des interactions; et 3) pris pour acquis l'engagement comme indice de satisfaction des bénévoles. Se fondant sur la perspective théorique offerte par l'interactionnisme symbolique, cet article maintient que l'engagement des bénévoles dépend de la manière dont ils interprètent leurs interactions avec les clients plutôt que des interactions elles-mêmes. Cette perspective met l'accent sur l'interaction dyadique entre le bénévole et le client, donne une place de choix au rôle social et à sa définition, et attire l'attention sur les stratégies employées par les bénévoles pour gérer des rapports parfois difficiles avec leurs clients.

Keywords / Mots clés Role commitment; Role theory; Social roles; Role maintenance strategies; Symbolic interactionist approach; Volunteering / Engagement envers un rôle; Théorie des rôles; Rôles sociaux; Stratégies d'entretien des rôles; Interactionnisme symbolique; Bénévolat

\section{INTRODUCTION}

There are numerous reports indicating the rate of attrition among volunteers as a persistent challenge for organizations. Research suggests that the retention of volunteers is sometimes more difficult than their recruitment (Behnia, 2007; 


\section{Behnia (2021)}

Green \& Chalip, 2004; Greenwood, Gordon, \& Bolton, 2016; Stefanick, Best-Bertwistle, \& Race 2020). The loss of volunteers is a loss not only for organizations but also for the individuals who receive their help (Goldman, 2002; Jamison, 2003; McNamee \& Peterson, 2015; Stefanick et al. 2020).

The high human and financial costs associated with losing volunteers have led researchers to investigate why individuals continue (discontinue) their volunteer work (Allen \& Mueller, 2013; Behnia, 2007; Musick \& Wilson, 2008; Wilson \& Musick, 1999). The answer to this question lies in the study of commitment. Defined as an intention to maintain or stay in a particular relationship, role, or identity over time, commitment is believed to influence one's current and future plan of conduct (Agnew \& Le, 2015; Byrd, 2009; Ebaugh, 1988; Stanley, Rhoades, \& Whitton, 2010; Turner, 2013; Wilson \& Musick, 1999).

A review of literature shows that in explaining volunteers' commitment, researchers have predominantly provided an individualistic account of volunteering by emphasizing volunteers' motivations, experiences of volunteering, and role identity. Influenced by motivational theories, researchers have purported that individuals remain committed when their altruistic and self-interest motivations (e.g., helping others, giving back to the community, meeting people, substituting their lost roles, learning new skills, and improving job opportunities) are fulfilled in the actual volunteer experience (Behnia, 2012, 2007, 2012; Green \& Chalip, 2004; Jensen, Lou, Aagaard, \& Vaeggemose, 2017; McCorkle, Dunn, Wan, \& Gagne, 2009; Musick \& Wilson, 2008; Rochester, Paine, \& Howlett, 2012; Schusterschitz, Flatscehr-Thon, Leiter-Scheiring, \& Geser, 2014; Smith, Drennan, Mackenzie, \& Greenwood, 2018; Snyder \& Omoto, 1992; Stefanick et al., 2020; Sturmer \& Snyder, 2010; van Ingen \& Wilson, 2017; Weng \& Lee, 2016; Wilson, 2012). Therefore, people continue their volunteer engagements to the extent to which the expectations and motivations that brought them to volunteer work are satisfied (Chacon, Vecina, \& Davila, 2007; Tang, Morrow-Howell, \& Choi, 2010).

Emphasizing the experiences of volunteering, researchers have observed that volunteers are more likely to remain committed when they feel connected to clients and peer volunteers, and are satisfied with their assigned tasks, organizational support, supervision, and the appreciation of their contribution (Behnia, 2012, 2007; Allen \& Mueller, 2013; Bussell \& Forbes, 2001; Haski-Leventhal \& Cnann, 2009; Musick \& Wilson, 2008; Rochester, Ellis Paine, \& Howlett, 2012; Snyder, Omoto, \& Crain, 1999; Stolinsky, Ryan, Hausmann, \& Wernli, 2004; van Ingen \& Wilson, 2017; Vecina, Chacon, Marzana, \& Marta, 2013; Wilson, 2000, 2012; Wilson \& Musick, 1999).

Researchers have also argued that volunteer commitment is a function of role identity. According to role identity theory, individuals have multiple roles. Role identity occurs when one of those roles becomes important to their sense of who they are and part of their self-concept (Musick \& Wilson, 2008; van Ingen \& Wilson, 2017). Once developed, role identity motivates individuals to remain engaged in behaviours consistent with their self-concept (Chacon, Vecina, \& Davila, 2007; Schusterschitz et.al., 2014). As people volunteer, some of them build a strong volunteer role identity (Penner, 2002; Rochester, Paine, \& Howlett, 2012; van Vianen, Nijstad, \& Voskuijl, 2008). The rate of turnover is believed to be lower among those individuals who strongly identify with the volunteer role compared to those with a weak role identity (Chacon et al., 2007; Musick \& Wilson, 2008; Schusterschitz et. al., 2014; van Ingen \& Wilson, 2017).

Drawing on the insights of a symbolic interaction approach, this article critically reviews the literature on the dynamics of volunteering and factors shaping volunteers' commitment. The review revealed important gaps in volunteering research and provided the context for proposing an alternative and more comprehensive approach to the study of volunteering. This article argues that despite their important contributions to the understanding of factors involved in volunteer commitment, researchers have overlooked 1) the interactional aspect of volunteer work, 2) the crucial role that interpretation plays in volunteer commitment, and 3) the presence of situations in which volunteers remain committed despite their dissatisfaction. 


\section{Behnia (2021)}

Taking a symbolic interactionist perspective, it is argued here that volunteering brings into contact two individuals with unique personal and social characteristics who are expected to define their role as help-giver and help-receiver and act accordingly. This perspective calls attention to the volunteer-client dyadic interaction, gives a prominent place to social role and its definition, and draws attention to the crucial role that the volunteers' interpretation of their interaction with clients has in their commitment.

The contention of this article is that volunteering is a complex, dynamic, and evolving social relationship, and its stability is associated with how volunteers interpret their interactions as well as the activities they enact to maintain the relationship. As discussed below, a symbolic interactionist approach (SI) provides a conceptual framework that can guide researchers in their investigation of volunteers' interpretation of their interaction with clients.

According to Herbert Blumer (1969), the SI approach rests upon three premises. First, humans "act toward things on the basis of the meanings that things have for them" (p. 2). As Blumer (2004) explains, an individual does not respond to another's action "on the basis of its mere presentation but instead interprets the gesture and responds to it on the basis of the interpretation" (p. 20). For instance, confronted by a person shaking a fist, one responds based on the way the gesture is defined. One may interpret that gesture to signify "that the person is angry, or bluffing, or indicating displeasure, or playfully feigning an attack" (p. 20; see also Blumer, 1967b). In other words, between the experienced events and the individual's response there is an intervening process of definition that is essential to the outcome (Blumer, 1967a).

The second premise is that the meaning is neither intrinsic to the object of attention nor brought to the relationship by the interacting individuals. Rather, meaning arises out of the social interaction that one has with a fellow human rather than in isolation (Becker \& McCall, 1990; Blumer, 1969; Hewitt, 1976; Sandstrom, Lively, Martin \& Fine 2014). Stressing the importance of social interaction in the formation of meaning and human conduct, Blumer (2004) writes that human behaviour is often explained as adhering to norms, carrying out role requirements, or pursuing motivations. Thus, social interaction is reduced to a mere medium for the play of factors, such as motivations, personality traits, social roles, and norms, that lie outside the interaction. In such an approach, social interaction adds nothing to the analysis or explanation of behaviour, as there is no recognition that social interaction "may limit, transform, or nullify" (p. 17) the behaviour of people involved in an interaction.

According to the third premise, the meanings are "handled in, and modified through, an interpretative process used by the person. Process is the correct one used by the person in dealing with the things he [sic] encounters" (Blumer, 2004, p. 2). During an interaction, individuals pause, monitor their reactions to the situation and their inner feelings, and reorganize and adjust their behaviour as they take account of the other person's actions. Thus, their definition of a situation can modify as the interaction proceeds and the participants respond to each other's act. In other words, before responding, there is a "pause," a "two-second delay while we mentally rehearse our next move, test alternatives, anticipate others' reactions" (Griffin, 2000, p. 56). This pause allows individuals to devise a response based on their definition of the situation. Therefore, even when a shaking fist is defined as a sign that an angry person is ready to launch an aggressive attack, it does not necessarily lead to fight or flight responses. One may "devise one of several responses, such as trying to bluff or mollify the perceived attacker, being contrite, 'joking the mater away,' or provoking the 'attacker' to greater anger" (Blumer, 2004, p. 21; see also Becker, 1972; Sandstrom et al.).

It is important to point out that although dissatisfaction with their role experience could strain and even undermine volunteers' commitment, their interpretation of their experience could lead to behaviours other than quitting. They may remain committed despite their dissatisfaction by resorting to "relationship maintenance strategies." Some of the strategies used by volunteers in such situations will be discussed in this article. The inclusion of such strategies will further enhance knowledge of the mechanisms involved in role commitment. 


\section{Behnia (2021)}

This article consists of four sections. The first section proposes a model of role commitment by applying the theoretical insights of the SI approach to social roles. Next, the outlined model is examined in light of the experiences of volunteers who work directly with clients who benefit from their work (e.g., befrienders, mentors), and the influence of the volunteerclient dyadic interaction on volunteers' self-concept, perceived self, and definition of the clients' identity is explored. In the following section, the relationship maintenance strategies used by volunteers are identified and discussed. Finally, the fourth section presents some of the implications of the proposed model for practice.

\section{ASYMBOLIC INTERCTIONIST MODEL OF ROLE COMMITMENT}

According to role theory, social roles refer to patterned behavioural expectations associated with social positions such as teachers, parents, citizens, neighbours, and friends that shape the conduct of individuals who occupy those positions (Biddle, 1986; Dolch, 2003; Newman \& Newman, 2007). There are, however, two major perspectives on social role: structural and symbolic interactionist approaches. Although these two perspectives agree that members of society are aware of the existence of norms of behaviour associated with social positions, they differ on the nature and influence of norms (Zurcher, 1983).

In a structural approach, social roles are conceived of as an already existing set of behavioural expectations associated with social positions that exist independently from human interaction and interpretation. Behaviours associated with social roles are learned by members of society through a socialization process. In this approach, individuals are "expected to conform to norms associated with their social position and to perform what they are supposed to do" (Biddle, 1986, p. 70). Normative requirements are, therefore, considered as objective forces that impinge upon the occupants of a social position and influence their conduct (Dolch, 2003; Hindin, 2007). In other words, whoever occupies these social positions knows "how to 'play' one's role - because the norms that define the role provide a script for any given situation in which one is called on to play the role" (Hewitt, 2003, p. 64; see also Frank, 2007; Heiss, 1981a; Zurcher, 1983).

A problem with a structural approach is that it views social roles as scripts that exist independent of the interaction process and the interpretation of the interacting individuals. Individuals think and act in ways that are consistent with the scripts. Social roles are, therefore, perceived as a static entity, and their negotiated and flexible nature is ignored (Asforth, 2001; Lopata, 1991). A symbolic interactionist approach provides a different view of social roles.

Although symbolic interactionists do not dispute the presence of normative behavioural expectations associated with social positions, they argue that roles are "behavioral expectations of what a person should do" (Musick \& Wilson, 2008, p. 421, emphasis added; see also Heiss, 1981a). An individual's definition of their role in an interactional context influences whether or not the individual follows role expectations and how they do that. However, role definition is not readily available. To define their role and align their actions accordingly, interacting individuals go through "role-taking" and "role-making" processes. Role-taking means imputing a role and identity to another person (e.g., student, parent, counsellor) and imaginatively occupying that role and looking at one's self and situation from that vantage point (Hewitt, 2003). It helps one anticipate the other's conduct (Stryker, 1967). In role-taking, individuals "read and interpret the other person's gestures through the prism of their own self, needs and stocks of accumulated knowledge" (Outhwaite \& Bottomore, 1996, p. 565; see also Turner, 2013).

By imputing a role to the other, an individual is not only able to adopt the other person's perspective and anticipate their behaviour, they are also able to "make" their own role (e.g., teacher, daughter, patient) (Blumer, 2004; Charon, 1995; Dolch, 2003; Hewitt, 1976; Lundgren, 2004; Turner, 1956, 1962). In role-making, individuals organize their actions in order to assert a role in a situation that affirms their self-concept and needs (Hewitt, 2003; Outhwaite \& Bottomore, 1996; Turner, 1994, 2013). 


\section{Behnia (2021)}

Charles Horton Cooley's concept of "looking glass" reveals that in addition to one's self-concept and definition of the other's identity, a third factor is also involved in one's role definition and conduct: the "perceived self." Cooley maintains that in our interactions with others, what we think others are thinking of our appearance, behaviours, and attributes evokes feelings (such as pride, gratification, resentment, frustration, or mortification) that could in turn shape our conduct (Heiss, 1981b; Lundgren, 2004; Rosenberg, 1979; Wallace \& Tice, 2012).

Once a role is defined, it functions as a perspective from which individuals construct their conduct (Hewitt, 2003; Turner, 1962). However, since role definition develops in the process of interaction between individuals, it is not static and inflexible (Dolch, 2003). Role definition is more akin to formulating a hypothesis, and as such it could be confirmed, revised, or even rejected as the relationship progresses and the interacting individuals learn more about each other (Hewitt, 1994; Turner, 1962, 1994). Because of their cognitive ability, individuals are able to "reflect about and assess the roles they are enacting or are supposed to enact. They can choose, for example, to let a role engulf their definition of self or can accommodate the behavioral expectations without at all defining themselves in terms of the role" (Zurcher, 1983, p. 34).

This article also posits the presence of two stages in role commitment: the pre-engagement and engagement stages. The pre-engagement stage refers to the period prior to undertaking a new role, when individuals prepare themselves through the "anticipatory role socialization process." This process assists individuals in their transition to a new role by helping them learn the values, skills, attitudes, and norms associated with the role to which they aspire to enter (Ebaugh, 1988). Anticipatory role socialization occurs through direct personal experience; conversation with relatives, friends, and acquaintances; and exposure to information via the media and the internet (Ebaugh, 1988; Haski-Leventhal \& Bargal, 2008; McCorkle et al., 2009; McNamee \& Peterson, 2015).

In pre-engagement, individuals imaginatively explore the consequences of entering the new role. They ponder whether they have the resources, capacities, and attributes required for the enactment of the new role (self-concept); the characteristics, expectations, and needs of those they will be interacting with (others' identity); and the potential judgements that those other individuals might make about their capacity in meeting the expectations and values associated with that role (perceived self). Individuals develop a preliminary commitment when these explorations lead to a positive orientation toward the role (Liou, 2008). However, this initial role definition and commitment could be challenged as volunteers engage with clients. Volunteers' commitment, therefore, hinges on congruence between expectations arising from their definition of their role as a volunteer and their experience of its enactment.

Applying these premises to volunteering, this article argues that one does not become a volunteer and fulfill the role by simply being matched with another person as a volunteer. To become a volunteer, individuals go through a process of role definition. A volunteer's self-concept, perceived self, and definition of other's identity influence their definition of their role and how they enact it. The presence of ambiguity in any of these three factors, or incompatibility between them, generates what role theorists call "problematic interaction situations," which could challenge the continuity of a relationship and result in a volunteer quitting or resorting to strategies for its maintenance.

To show the significance of the proposed model in shedding light on the dynamics of volunteer-client interaction and role commitment, volunteers' reports of their face-to-face interactions with clients are examined in relation to their self-concept, their definition of client's identity, and their perceived self. More specifically, the literature focusing on the volunteers' definition of their dyadic interactions with clients is explored, seeking answers to the following questions: What are the underlying reasons for volunteers' defining their interactions as satisfactory or disappointing? What are the factors influencing such interpretations of their experience? What are the key mechanisms keeping them committed to their relationships? 


\section{Behnia (2021)}

\section{Application of the role commitment model}

Other's identity

Volunteering is not a spontaneous and random form of helping activity, it is an action based on reflection and selection. Individuals screen various volunteer programs and their potential clients in order to select the desired one (Behnia, 2007; Vecina et al., 2013). In other words, volunteers do not work with just anyone (Froyum, 2018). They are drawn to a certain group of individuals based on their perception of that group. They are attracted to clients who, in their view, need and deserve their help (Musick \& Wilson, 2008). According to Carissa Froyum (2018), the clients must be conceived of as needy (i.e., suffering from a shortage of material and social resources), blameless (i.e., not be responsible for their need for help), and willing to be changed in order to be considered as deserving.

Social identity is another factor that draws individuals to volunteer with certain social groups. According to social identity theory, the perceived similarities and connections lead people to view themselves as members of the same social group (in-group) compared to others who do not belong to that group (out-group). Thus, individuals have a tendency to gravitate toward people with common ethnic, gender, class, and professional backgrounds. Consequently, the stronger an individual feels connected with a particular group, the more inclined that person is to volunteer for members of that group (Doidge \& Sandri, 2018; Haski-Leventhal \& Cnann, 2009; Lester, Mead, Graham, Gask, \& Reilly, 2011; McCorkle et al., 2009; Sabir, Pillemer, Suitor, \& Patterson, 2003; Smith et al., 2018; Stukas, Snyder, \& Clary, 2015; Weng \& Lee, 2016). Conversely, individuals may refrain from volunteering with some groups, such as people with HIVIAIDS and refugees, due to the stigma and stereotypes associated with their identity (Behnia, 2007; Musick \& Wilson, 2008; Snyder, Omoto, \& Crain, 1999; Snyder \& Omoto, 1992; Stolinski et al., 2004; Wilson, 2000).

Training and orientation sessions provided by volunteer organizations are also critically important in shaping prospective volunteers' image of their clients and their needs (Holden, 1997; Jensen, Lou, Aagaard, \& Vaeggemose, 2017; Kramer, 2010; Lilburn, Breheny, \& Pond, 2018; McCorkle et al., 2009; Musick \& Wilson, 2008; Thompson, Valenti, Siette, \& Priebe, 2016). The content of training is reported to generate concern and trepidation among the prospective volunteers (Greenwood et al., 2016). For instance, in a training program for mentors, the youth with whom volunteers were to be matched were portrayed as "deliberately telling lies, engaging in criminal activities, abusing alcohol and drugs, having suffered child abuse, or being schizophrenic or suicidal" (Colley, 2003, p. 65). After the training, some participants relayed that the training had "generated a sense of fear about the young people whom they might be mentoring" (Colley, 2003, p. 66).

Volunteers, therefore, enter the helping relationship with a preliminary definition of who the clients might be and what values and needs they might have. Brian McCorkle, Erin Dunn, Yu Mui Wan, and Cheryl Gagne (2009), for example, report that prior to meeting their clients, participants in their study expected "to share a client's life transformation, similar to the Hollywood movies Shine and A Beautiful Mind" (p. 296; see also Damianakis, 2007).

However, the actual experience of volunteering could challenge these preliminary notions. Volunteers' initial positive feeling could change as the relationship progresses and they get to know the clients. Clients' deservingness, for instance, could be questioned when volunteers disapprove of clients' conduct and attitudes. Helen Colley (2003) reports that after a few months of mentoring, a mentor's view about the mentee was changed, and their relationship was negatively affected as a result. Adopting a discourse of deviance, the mentor talked about the mentee "in terms of benefit dependency, unwillingness to work, teenage pregnancy, lack of respect for educational values" (p. 91).

Emotions such as confusion, disappointment, frustration, and anger could emerge when a volunteer's initial expectations are not met (Jensen et al., 2017). Disappointment with the relationship can at times be so strong that it can lead volunteers to contemplate quitting. A volunteer who was born to immigrant parents and witnessed the challenges they faced in ad- 


\section{Behnia (2021)}

justing to Canadian society, for example, enthusiastically began volunteering with an older adult immigrant. Initially, she appraised their relationship as "excellent" and talked about their common interests and "ways of thinking." However, after a few meetings, the volunteer became so frustrated with the client's confrontational and challenging behaviours that she talked about ending the relationship (Behnia, 2018).

The volunteer-client relationship is also affected by whether volunteers conclude that a client's claim about their needs is true and that they are not taking advantage of them (Musick \& Wilson, 2008). For example, some volunteers who worked with refugees with demanding needs discontinued their work because they felt the refugees were exploiting them (Behnia, 2007).

\section{Self-concept}

Volunteers enter the helping relationship believing to possess personal resources and capacities relevant to the volunteer role, such as compassion, patience, friendliness, flexibility, persistence, a positive outlook, leadership, listening skills, and caring skills (Behnia, 2012; Keith, 2003; Lilburn et al., 2016; Stefanick et al., 2020; Wharton, 1991). Their perception of the relevance of their skills and traits comes from their assumptions about a client's life experience and needs. For instance, a friendly visitor who assumed that residents of a nursing home were not appreciative of their lives stated: "I can make them see the bright side of each day because I love life and feel each day as a gift of God" (Keith, 2003, p. 26).

These perceptions make individuals feel confident enough to join volunteer organizations. Self-efficacy or confidence in having the skills and capacities necessary for the completion of volunteer tasks, for example, encouraged Canadianborn individuals to engage in volunteer work with newcomers. They believed that their training in mediation, teaching experience, years of working in the community, and travel abroad enabled them to overcome the challenges of working with immigrants (Behnia, 2012). The presence of similar personal experiences may also make individuals believe in their ability to work with certain groups (McNamee \& Peterson, 20156). Immigrant volunteers, for instance, reported that they did not anticipate any challenges in working with newcomers. The presence of a common past gave immigrant volunteers confidence that they had a good understanding of the difficulties newcomers confront and were, therefore, in a better position to help them (Behnia, 2012).

Volunteers come to the helping relationship with an imaginative view of who they are and what personal skills and competencies they bring to the relationship. In other words, they bring a role identity that consists both of the behavioural expectations associated with the new role and their personal identity (Turner, 2013). However, engagement with clients could challenge their role identity as a volunteer. In a study of volunteers working with street youth in Israel, volunteers reported that before meeting clients they imagined themselves as adult role models who were there to save the youth by showing them the right way, and that they expected to be accepted as such by the youth. However, contrary to their expectation, the street youth not only did not "accept their help with open arms but rather put them through some hard trials and tests, and the volunteers had to prove they were worthy" (Haski-Leventhal \& Bargal, 2008, p. 82).

The performance of tasks that contradict volunteers' self-concept could call into question their perception of themselves as a good person. Daphne Holden (1997) reports that college students who began their volunteer work with a homeless shelter with a desire to treat homeless people respectfully as equals, experienced an identity crisis when they found out that their role was to "enforce shelter rules, to spy into residents' lives, and to order around the very people whom they came to help" (p. 123). All the volunteers reported anxiety and discomfort about the organization's behavioural expectations, with one volunteer stating: "It's hard for me because I want to be on, like, equal ground, like feel equal to them and not feel a superior or something because it's not my situation" (Holden, 1997, p. 124). 


\section{Behnia (2021)}

A sense of self-efficacy or confidence in their ability to complete the assigned tasks is another important factor in sustaining a volunteer's commitment. Seeing the positive effects of their volunteer work generates a sense of fulfillment and functions as a major reason to stay committed (Behnia, 2012; Green \& Chalip, 2004; Smith et al. 2018). In contrast, volunteers may become disappointed when, contrary to their expectation of being a helping and resourceful person, they realize they are not making a difference or helping (Musick \& Wilson, 2008). For instance, volunteers working with refugees reported experiencing disappointment when they were unable to prevent the deportation of refugees with whom they were matched or were unable to provide the sureties that imprisoned refugees were looking for (Behnia, 2007). Volunteers working with newcomers, for instance, reported that they remained committed because they felt helpful. If I didn't see progress then I might get a little umm, maybe a little bit disappointed not in my students but in myself, that I wasn't able to get her to a level that was helpful for her. (Behnia, 2012, p. 17)

Consequently, a lack of feedback made some volunteers uncertain about their self-efficacy: "Sometimes you have somebody, nothing is said, no expression is said. So then you have this feeling of confusion of 'did I really help him or not?'" (Behnia, 2012, p. 17).

\section{Perceived self}

Researchers have pointed out a link between volunteering and moral identity. Helping others without expectation for financial remuneration has generated the assumption that to be a volunteer is to be an altruistic and good person (Froyum, 2018; Holden, 1997; McNamee \& Peterson, 2015; Musick \& Wilson, 2008). While the "volunteer" identity carries positive moral value, whether or not clients and significant others (e.g., supervisors, relatives, friends) respond positively to this valued identity could engender different conduct in volunteers and impact their perception of self. Lacy G. McNamee and Brittany L. Peterson (2015) report that a study participant who was criticized by her supervisor said, "You hear that over and over and over, [and] you begin to wonder whether you're doing it right or not - especially if you never get any positive feedback" (p. 285). It is reported that the volunteers most likely to quit are those who received no recognition and appreciation for their work (Caro \& Bass, 1995; Musick \& Wilson, 2008). Clients' recognition of the contributions of volunteers and a show of gratitude for the help they receive are perceived as their positive perception of volunteers (Musick \& Wilson, 2008).

Another important factor that shapes volunteers' experiences is feeling that they matter. Mattering is defined as a perception that we are an object of other people's attention, that they care about our lives and what we think, want, and do, and that they rely on us and we make a difference to their lives (Flett, 2018; Rosenberg \& McCullough, 1981). As Jane Piliavin and Erica Siegl (2007) point out, mattering involves feeling "good about oneself," which is generated by the perception that people "notice us, care that we exist, and value us" (p. 452).

Therefore, the positive attention shown by clients conveys the message that volunteers matter to them. For instance, volunteers felt they mattered when older adult clients treated them as though they were their family members, looking after them, checking in on them, and expressing interest in their life and well-being (Behnia, 2018). Conversely, when clients do not return a volunteer's phone calls, do not show up for appointments, and do not share personal information, it can make volunteers feel rejected and as it they do not matter (Behnia, 2007; Greenwood et al., 2016). A volunteer who believed that a client "chose to reveal little about himself" reported that the "[client is] just regarding me as some kind of [servant] ... like some kind of lower-order being that's been brought in to provide a service for him that he requires and, beyond being polite [pause] he doesn't have to deal with me as a person, and that made me angry" (Greenwood, et al., 2016, p. 7). This perception made the volunteer wonder whether he could continue the relationship. 


\section{Behnia (2021)}

\section{RELATIONSHIP MAINTENANCE STRATEGIES}

Dissatisfaction caused by the discrepancy between expectation and experience does not always result in volunteers ending their relationship with clients, leading to the question of why some volunteers continue their volunteer work despite a dissatisfactory experience. This question draws attention to the insights of scholars who have pointed out that people "spend more time maintaining relationships than developing or dissolving them" (Duck, 1988, cited in Stafford, 2003, p. 52). Research shows that people often engage in relational maintenance efforts in order to "stabilize a relationship that has gone through tough times and to keep it in a satisfactory condition." This explains the presence of "seeming anomalies such as stable, unhappy marriages" (Canary \& Dainton, 2006, p. 728).

To maintain the continuity and stability of these relationships and to keep them from further deterioration, people often resort to what scholars have called "relationship maintenance strategies." These strategies refer to efforts to keep existing relationships, including those that are going through difficult time (Canary \& Dainton, 2006). There are cognitive and behavioural strategies of relationship maintenance.

The cognitive strategies refer to the non-interactive processes undertaken by individuals when they face a challenging relationship (Canary \& Dainton, 2006; Harvey \& Wenzel, 2006). The cognitive strategies include mental activities such as minimizing, ignoring, forgiving, reframing, and justifying someone else's transgression (Canary \& Dainton, 2006; Kivisto \& Pittman, 2005; Rusbult, Agnew, \& Arriaga, 2012).

One of the cognitive strategies used by volunteers to sustain their commitment to a challenging relationship is to blame external factors. According to attribution theory, when individuals blame themselves for a failure, it is likely they have negative feelings about themselves. However, when external or situational factors are identified as the causes of a problem, there is a higher likelihood that their self-concept is not being threatened (Gecas \& Schwalbe, 1983; Zurcher, 1983).

Unsatisfactory role enactment could challenge a volunteer's self-concept as a capable and resourceful person. To protect this self-concept and stay in a relationship, a volunteer may blame other individuals and social forces. Froyum (2018), for instance, describes how a volunteer matched with children tried to deflect responsibility for the children's failure to progress by blaming bad parenting, a bad neighborhood, poverty, and delinquent peers.

Blaming circumstance is also helpful in maintaining a relationship because it confirms that clients deserve to be helped. Clients deserve support because their needs are caused by circumstances beyond their control (Behnia, 2012; Doidge \& Sandri, 2018; Froyum, 2018). To continue their volunteer work with challenging immigrant seniors, volunteers resorted to various cognitive strategies: some thought of clients as children attempting to get attention, "[You deal with them] like you deal with a little kid about the age four-five years old. ... They need your attention, they need your love"; some explained clients' troublesome behaviours as signs of low self-esteem, "They think 'nobody knows me,' 'I am nobody' ... 'nobody loves me"'; and some even used ageist interpretations to explain the seniors' difficult behaviours, "When you get old, [your brain] is gone ... Because the brain is shrinking" (Behnia, 2018, p. 44).

Finally, another strategy used by volunteers was to change their mindset. Diane Greenwood, Carolyn Gordon, Claire Pavlou, and Jessica Bolton (2016) report that the befrienders matched with people with dementia often feel "tired, bored or frustrated, and even questioning their ability to 'go on." But many of them "talked about the influence of their mindset on coping with the emotional challenges of the befriending role. They perceived difficulties like predictability as an inevitable part of the role and therefore saw themselves as responsible for managing their emotions: "It's only tiring if I let it be ... and if I let that get me then that's my problem, it's not him"' (p. 11; see also McCorkle et al., 2009). 


\section{Behnia (2021)}

The behavioural strategies of relationship maintenance refer to behaviours or interactions that individuals enact to sustain a relationship. They go from acting nicely, withholding complaints, avoiding arguments, and supporting and comforting the transgressor to confronting them by setting boundaries and expressing anger and frustration (Canary \& Dainton, 2006).

Volunteering often brings people of different social, economic, and cultural backgrounds into an unequal relationship, where one provides support and the other receives the support. Interactions with clients could make volunteers aware of differences in their identity such as age, gender, race, class, and sexual orientation. That could become a source of concern for being negatively judged and even rejected by clients. To prevent that, some volunteers may resort to the strategy of hiding aspects of their identity. For instance, volunteers who worked in a homeless shelter tried to hide class gaps between them and the homeless people by avoiding talking about their vacations with the residents (Holden, 1997). Concerned about her client's reaction to their class difference, another volunteer reported that whenever she visited the teenage mother,

I dress down, I don't wear jewelry, I go with the smallest car. I haven't even gotten her out to my house yet because I don't know what she would think. I have a big house in a nice neighborhood, and she lives in this little tiny place. (Wharton, 1991, p. 99)

Another behavioural strategy used by volunteers is to create situations congruent with their self-concept. For instance, to protect themselves against the negative judgement of shelter residents, volunteers avoided enforcing rules by pretending to be ignorant of how to handle them. They asked the paid staff to enforce rules. Another strategy they used was to take the night shifts. This allowed them to have more time to talk to shelter residents and build friendlier relationships with them (Holden, 1997; Musick \& Wilson 2008). Other volunteers used this "avoidance" strategy to maintain their relationship with clients. For instance, when there was a history of animosity between their countries of origin, volunteers tried to avoid any discussion around politics with clients (Behnia, 2018).

Finally, to maintain relationships, some volunteers verbalized their frustration. One volunteer, for instance, reported that: "There was no joy in it for me by going and picking her up and taking her to whatever store she wanted to go to. I knew I wouldn't last like that. So I started setting limits and explaining to her that that's not what friends do" (McCorkle et al., 2009, p. 295).

\section{CONCLUSION}

Conceiving of volunteering as a role enactment, this article explored factors associated with volunteers' commitment to their roles, as well as some of the strategies they use to sustain unsatisfactory relationships. Informed by a symbolic interactionist approach, this article investigated role commitment in relation to volunteers' interpretation of their interactions with the clients. The application of a symbolic interaction approach showed that to define their role, volunteers go through role-taking and role-making processes by collecting and interpreting interactional cues along three parameters: their selfconcept, their definition of the client, and their perceived self.

Conceptualizing role definition and commitment as a two-stage process, this article also examined the influence of the anticipatory role socialization process in shaping the perspective of prospective volunteers regarding a potential new role. In the pre-engagement stage, the prospective volunteers construct an image of themselves in the role, clients with whom they will be matched, and the view that clients might have of them. This process results in the development of certain expectations about themselves and clients, which could be confirmed or challenged in the engagement stage. Whether volunteers remain committed in the face of a discrepancy between expectations and experiences depends on how they interpret their relationship with clients. Volunteers may stay committed by resorting to cognitive and behavioural strategies that allow them to frame challenging relationships as acceptable. 


\section{Behnia (2021)}

The proposed conceptual model could enhance the retention capacity of organizations by helping them to see the interactional aspects of volunteer-client relationships and the crucial role interpretation plays in their maintenance.

Organizations can play an important role in promoting volunteers' commitment by assisting them in the interpretation of their interaction with clients. Considering that due to anticipatory role socialization, volunteers come to the helping relationship with a certain conception of themselves and the clients, organizations need to 1) use the initial interviews and orientation sessions to elicit volunteers' perspectives in order to identify any misconceptions and unrealistic expectations that could negatively influence their interpretation of their interactions with the clients; and 2) organize informal community events to create opportunities for volunteers to meet and interact with clients, more experienced volunteers, and staff (Behnia, 2018; Stevens, 1991).

Once volunteers commence their volunteer work, organizations should provide them with ongoing follow-up and support. These activities allow the organizations to check in on how things are going, hear about volunteers' experiences with clients and volunteer works, and monitor volunteers' perceptions of their self-concept and perceived self, and see whether intervention is necessary to reduce confusion, doubt, and frustration.

Access to appropriate information about clients' background, interests, culture, support networks, and special needs helps volunteers in their search to define a client's identity (Damianakis, Wagner, Bernstein \& Marziali, 2007; Jensen et al., 2017). This information could help volunteers have greater insight into the potential impact of their background differences. For instance, some refugees may be reluctant to share personal information and talk about their pre-migration life due to their past traumatic life experiences. Some befrienders, however, have reported perceiving distrustful behaviour as a sign of rejection and, therefore, a source of resentment (Behnia, 2007).

Volunteers need training workshops on issues such as socio-cultural differences, biases, and stereotypes and the effects they can have on their relationships with clients and how to address that. This training could help volunteers interpret their interactions with clients.

Finally, the appreciation shown by clients and organizations is an important factor encouraging volunteers to continue their work. It not only boosts their sense of accomplishment and self-efficacy, it can also convey a feeling of being positively perceived by others (perceived self). Therefore, it is important that organizations inform volunteers of the clients' positive feedback and appreciation of their contributions. Organizations' official recognition of volunteers furthers volunteer commitment (Behnia, 2012; Kovacs \& Black, 1999).

\section{ACKNOWLEDGEMENTS}

I would like to thank Faranak Aminzadeh and the three anonymous reviewers for their helpful comments and suggestions.

\section{REFERENCES}

Agnew, C.R., \& Le, B. (2015). Prosocial behavior in close relationships: An interdependence approach. In D.A. Schroeder \& W.G. Graziano (Eds.). The Oxford Handbook of Prosocial Behavior (pp. 362-375). Oxford, UK: Oxford University Press.

Allen, J.A., \& Mueller, S.L. (2013). The revolving door: A closer look at major factors in volunteers' intention to quit. Journal of Community Psychology, 41(2), 139-155.

Ashforth, B.E. (2001). Role transitions in organizational life. An identity-based perspective. London, UK: Lawrence Erlbaum Associates Publishers. 


\section{Behnia (2021)}

Becker, H.S. (1967). Becoming a marihuana user. In J.G. Manis \& B.N. Meltzer (Eds.), Symbolic interaction. A reader in social psychology (pp. 411-422). Boston, MA: Allyn and Bacon.

Becker, H.S. \& McCall, M.M. (Eds.) (1990). Symbolic Interaction and Cultural Studies. Chicago: The University of Chicago Press.

Behnia, B. (2007). An exploratory study of befriending programs with refugees: The perspective of volunteer organizations. Journal of Immigrant and Refugee Studies, 5(3), 1-19.

Behnia, B. (2012). Volunteering with Newcomers: The perspectives of Canadian- and foreign-born volunteers.

Canadian Journal of Non-Profit and Social Economy Research, 3(2), 6-23.

Behnia, B. (2018). Befriending with socially isolated immigrant seniors. International Journal of Volunteer Administration, $33(1), 36-51$.

Biddle, B.J. (1986). Recent developments in role theory. Annual Review of Sociology, 12, 67-92.

Blumer, H. (1967a). Sociological analysis and the "variable." In J.G. Manis \& B.N. Meltzer (Eds.), Symbolic interaction: A reader in social psychology (pp. 84-94). Boston, MA: Allyn and Bacon.

Blumer, H. (1967b). Society as symbolic interaction. In J.G. Manis \& B.N. Meltzer (Eds.), Symbolic interaction: A reader in social psychology (pp. 139-148). Boston, MA: Allyn and Bacon.

Blumer, H. (1969). Symbolic interactionism: Perspective and method. Englewood Cliffs, NJ: Prentice-Hall Inc.

Blumer, H. (2004). George Herbert Mead and Human Conduct. New York: Altamira Press.

Bussell, H., \& Forbes, D. (2001). Understanding the volunteer market: The what, where, who and why of volunteering. International Journal of Nonprofit and Voluntary Sector Marketing, 7(3), 244-257.

Byrd, S.E. (2009). The social construction of marital commitment. Journal of Marriage and Family, 71(2), 318-336.

Canary, D.J. \& Dainton, M. (2006). Maintaining relationships. In A.L. Vangelisti \& D. Perlman (Eds.), The Cambridge handbook of personal relationships (pp. 485-499). Cambridge, UK: Cambridge University Press.

Caro, F.G., \& Bass, S.A. (1995). Increasing volunteering among older people. In S. Bass (Ed.), Older and active. How Americans over 55 are contributing to society (pp. 71-96). New Haven, CT: Yale University Press.

Chacon, F., Vecina, M.L., \& Davila, M.C. (2007). The three-stage model of volunteers' duration of service. Social Behavior and Personality, 35(5), 627-642.

Charon, J.M. (1995). Symbolic interactionsim. An introduction, an interpretation, and integration (5th edition). Englewood Cliffs, NJ: Prentice-Hall.

Colley, H. (2003). Mentoring for social inclusion. A critical approach to nurturing mentor Relationships. London, UK: Routledge Falmer.

Cooley, C.H. (1967). Looking-Glass Self. In J.G. Manis \& B.N. Meltzer (Eds.), Symbolic interaction. A reader in social psychology (pp.217-220). Boston, MA: Allyn and Bacon.

Damianakis, T., Wagner, L.M., Bernstein, S., \& Marziali, E. (2007). Volunteers' experiences visiting the cognitively impaired in nursing homes: A Friendly visiting program. Canadian Journal on Aging, 26(4), 343-356.

Dolch, N.A. (2003). Role. In L.T. Reynolds \& N.J. Herman-Kinney (Eds.), Handbook of Symbolic Interactionism, (pp. 391-410). Lanham, MD: Altamira Press.

Doidge, M., \& Sandri, E. (2018). Friends that last a lifetime: The importance of emotions amongst volunteers working with refugees in Calais. The British Journal of Sociology, 70(2), 463-480.

Ebaugh, H.R. (1988). Becoming an ex: The process of role exit. Chicago, IL: The University of Chicago Press.

Flett, G.L. (2018). The psychology of mattering: Understanding the human need to be significant. London, UK: Academic Press.

Frank, D.D. (2007). Role. In G. Ritzer (Ed.), The Blackwell Encylopedia of Sociology (Vol. 8), (pp. 3945-3948). Malden, MA: Blackwell Publishing Ltd.

Froyum, C. (2018). "They are just like you and me": Cultivating volunteer sympathy. Symbolic Interaction, 241(4), 465-487. 


\section{Behnia (2021)}

Gecas, V., \& Schwalbe, M. (1983). Beyond the looking-glass self: Social structure and efficacy-based self-esteem. Social Psychology Quarterly, 46(2), 77-88.

Goldman, L.M. (2002). The friendly companion program. Journal of Gerontological Social Work, 40(1/2), 123-133.

Green, C.B., \& Chalip, L. (2004). Paths to volunteer commitment: Lessons from the Sydney Olympic Games. In R.A. Stebbins \& M.Graham (Eds.), Volunteering as leisure/leisure as volunteering. An international assessment (pp. 49-68). Cambridge, MA: CABI Publishing.

Greenwood, D.E., Gordon, C., Pavlou, C., \& Bolton, J.V. (2016). Paradoxical and powerful: Volunteers' experiences of befriending people with dementia. Dementia, 17(7), 821-839.

Griffin, E. (2000). A first look at communication theory (4th edition). Boston, MA: McGraw Hill Higher Education.

Harvey, J.H., \& Wenzel, A. (2006). Theoretical perspectives in the study of close relationships. In A.L. Vangelisti \& D. Perlman (Eds.), The Cambridge handbook of personal relationship (pp. 35-50). Cambridge, UK: Cambridge University Press.

Haski-Leventhal, D., \& Bargal, D. (2008). The volunteer stages and transitions model: Organizational socialization of volunteers. Human Relations, 61(1), 67-102.

Haski-Leventhal, D., \& Cnann, R.A. (2009). Group processes and volunteering: Using groups to enhance volunteerism. Administration in Social Work, 33(1), 61-80.

Heiss, J. (1981a). Social roles. In M. Rosenberg \& R.H. Turner (Eds.), Social psychology: Sociological perspectives (pp. 94-129). New York, NY: Basic Books Inc. Publishers.

Heiss, J. (1981b). The social psychology of interaction. Englewood Cliffs, NJ: Prentice-Hall, Inc.

Hewitt, J.P. (1976). Self and society: A symbolic interactionist social psychology. Boston, MA: Allyn and Bacon.

Hewitt, J.P. (1994). Self, role, and discourse. In G.M. Platt \& C. Gordon (Eds.), Self, collective behavior and society: Essays honouring the contributions of Ralph H. Turner (pp. 155-173). London, UK: JAI Press Inc.

Hewitt, J.P. (2003). Self and society: A symbolic interactionist social psychology (9th edition). Boston, MA: Allyn and Bacon.

Hindin, M.J. (2007). Role theory. In G. Ritzer (Ed.), The Blackwell encylopedia of sociology (Vol. 8) (pp. 3951-3954). Malden, MA: Blackwell Publishing Ltd.

Holden, D. (1997). "On equal ground": Sustaining virtue among volunteers in a homeless shelter. Journal of Contemporary Ethnography, 26(2), 117-145.

Jamison, I.B. (2003). Turnover and retention among volunteers in human service Agencies. Review of Public Personnel Administration, 23(2), 114-132.

Jensen, L.G., Lou, S., Aagaard, J., \& Vaeggemose, U. (2017). Community families: A qualitative study of families who volunteer to support persons with severe mental illness. International Journal of Social Psychology, 63(1), 33-39.

Keith, P.M. (2003). Doing good for the aged. Volunteers in an ombudsman program. Westport CT: Praeger.

Kivisto, P., \& Pittman, D. (2005). Goffman's dramaturgical sociology: Personal sales and service in a commodified world. In P. Kivisto (Ed.), Illuminating social life: Classical and contemporary theory revisited (3rd edition) (pp. 259-279). Thousand Oaks, CA: Pine Forge Press.

Kramer, M.W. (2010). Organizational socialization. Joining and leaving organizations. Cambridge, UK: Polity Press.

Lester, H., Mead, N., Graham, C.C., Gask, L., \& Reilly, S. (2012). An exploration of the value and mechanisms of befriending for older adults in England. Ageing \& Society, 32(2), 307-328.

Lilburn, L.E.R., Breheny, M., \& Pond, R. (2018). "You're not really a visitor, you're just a friend": How older volunteers navigate home visiting. Ageing \& Society, 38(4), 817-838.

Liou, S-R. (2008). An analysis of the concept of organizational commitment. Journal of Compilation, 43(3), 116-125.

Lopata, H.Z. (1991). Role theory. In J.R. Blau \& N.Goodman (Eds.), Essays in honor of Rose Laub Coser social roles and social institutions (pp. 1-11). Boulder, CO: Westview Press. 


\section{Behnia (2021)}

Lundgren, D.C. (2004). Social feedback and self-appraisals: Current status of the mead-cooley hypothesis. Symbolic Interaction, 27(2), 267-286.

McCorkle, B.H., Dunn, E.C., Wan, Y.M., \& Gagne, C.L. (2009). Compeer friends: A qualitative study of a volunteer friendship programme for people with serious mental illness. International Journal of Social Psychiatry, 55(4), 291-305.

McNamee, L.G. \& Peterson, B.L. (2015). High-Stakes volunteer commitment: A qualitative analysis. Nonprofit \& Voluntary Sector Quarterly, 45(2), 275-294.

Musick, M.A., \& Wilson, J. (2008). Volunteers. A social profile. Bloomington \& Indianapolis, IN: Indiana University Press.

Newman, B.M., \& Newman, P.R. (2016). Theories of human development (2nd edition). New York, NY: Psychology Press.

Outhwaite, William, \& Bottomore, Tom (Eds.). (1996). The black dictionary of twentieth-century social thought. Oxford, UK: Blackwell Publishers Ltd.

Penner, L.A. (2002). Dispositional and organizational influences on sustained volunteerism: An interactionist perspective. Journal of Social Issues, 58(3), 447-467.

Piliavin, J.A., \& Siegl, E. (2007). Health benefits of volunteering in the Wisconsin Longitudinal Study. Journal of Health and Social Behavior, 48(4),450-464.

Rochester, C., Ellis Paine, A., \& Howlett, S. (2012). Volunteering and society in the 21st century. New York, NY: Palgrave Macmillan.

Rosenberg, M. (1979). Conceiving the self. New York, NY: Basic Books Publishers.

Rosenberg, M., \& McCullough, B.C. (1981). Mattering: Inferred significance and mental health among adolescents. Research in Community and Mental Health, 2, 163-182.

Rusbult, C.E., Agnew, C.R., \& Arraiga, X.B. (2012). The investment model of commitment processes. In P.A.M. van Lange, A.W. Kruglansk, \& E.T. Higgins (Eds.), Handbook of person, memories of social psychology (Vol. 2) (pp. 218-231). Los Angeles, CA: SAGE.

Sabir, M., Pillemer, K., Suitor, J., \& Patterson, M. (2003). Predictors of successful relationships in a peer support program for Alzheimer's caregivers. American Journal of Alzheimer's Disease and Other Dementias, 18(2), 115-122.

Sandstrom, K.L.; Lively, K.J.; Martin, D.D. \& Fine G.A. (2014). Symbols, Selves, and Social Reality. A Symbolic Interactionist Approach to Social Psychology and Sociology (4th edition) (pp. 123-163). Oxford: Oxford University Press.

Schusterschitz, C., Flatscehr-Thon, M., Leiter-Scheiring, A., \& Geser, W. (2014). Building a committed hospice volunteer workforce: Do variables at the experience stage matter? Journal of Community and Applied Social Psychology, 24(5), 422-438.

Smith, R., Drennan, V., Mackenzie, A., \& Greenwood, N. (2018). Volunteer peer support and befriending for cares of people living with dementia: An exploration of volunteers' experiences. Health and Social Care in the Community, 26(2), 158-166.

Snyder, M., Omoto, A.M., \& Crain, A.L. (1999). Punished for their good deeds. Stigmatization of AIDS volunteers. American Behavioral Scientist, 42(7), 1175-1192.

Snyder, M., \& Omoto, A.M. (1992). Who helps and why? The psychology of AIDs volunteerism. In S. Spacapan \& S. Oskamp (Eds.), Helping and being helped. Naturalistic studies, (pp. 213-239). London, UK : Sage publications, Inc.

Stafford, L. (2003). Maintaining romantic relationships: Summary and analysis of one research program. In D.J. Canary \& M. Dainton (Eds.), Maintaining relationships through communication. Mahwah, NJ: Lawrence Erlbaum Associates.

Stanley, S.M., Rhoades, G.K., \& Whitton, S.W. (2010). Commitment: functions, formation, and the securing of romantic attachment. Journal of Family Theory \& Review, 2(4), 243-257.

Stefanick, Lorna, Best-Bertwistle, Rebecca, \& Race, Lynsey S. (2020). Retaining volunteers in the age of precarious work. Journal of Nonprofit \& Public Sector Marketing, 32(2), 124-146.

Stolinski, A., Ryan, C., Hausmann, L.R., \& Wernli, M.A. (2004). Empathy, guilt, volunteer experiences, and intentions to continue volunteering among buddy volunteers in an AIDS organization. Journal of Applied Biobehavioral Research, 9(1), 1-22. 


\section{Behnia (2021)}

Stryker, S. (1967). Symbolic interaction as an approach to family research. In J.G. Manis \& B.N. Meltzer (Eds.), Symbolic interaction. A reader in social psychology (pp. 371-383). Boston, MA: Allyn and Bacon.

Stukas, A.A., Snyder, M., \& Clary, G. (2015). Volunteering and community involvement: Antecedents, experiences, and consequences for the person and the situation. In D.A. Schroeder \& W.G. Graziano (Eds.), The Oxford handbook of prosocial behavior, (pp. 459-493). Oxford, UK: Oxford University Press.

Sturmer, S., \& Snyder, M. (2010). The psychosocial study of group processes and intergroup relations in prosocial behavior: Past, present, future. In S. Sturmer \& M. Snyder (Eds.), The psychology of prosocial behavior (pp. 3-12). Chichester, UK: John Wiley and Sons.

Tang, F., Morrow-Howell, N., \& Choi, E. (2010). Why do older adult volunteers stop volunteering? Ageing \& Society, 30(5), 859-878.

Thompson, R., Valenti, E., Siette, J., \& Priebe, S. (2016). To befriend or to be a friend: A systematic review of the meaning and practice of "befriending" in mental health care. Journal of Mental Health, 25(1), 71-77.

Turner, J.H. (1994). Roles and interaction processes: Toward a more robust theory. In G.M. Platt \& C. Gordon (Eds.), Self-collective behavior and society: Essays honoring the contributions of Ralph H. Turner (pp. 359-376). London, UK: JAI press Inc.

Turner, J.H. (2013). Theoretical sociology 1830 to the present. Los Angeles, UK: Sage.

Turner, R.H. (1956). Role-taking, role standpoint, and reference-group behavior. The American Journal of Sociology, 61(4), 316-328.

Turner, R.H. (1962). Role-taking: Process versus conformity. In A.M. Rose (Ed.), Human behavior and social processes: An interactionist approach (pp. 20-40). Boston, MA: Houghton Mifflin Company.

Van Ingen, E. \& Wilson, J. (2017). I volunteer, therefore I am? Factors affecting volunteer role identity. Non-profit and Voluntary Sector Quarterly, 46(1), 29-46.

Van Vianen, A.E., Nijstad, B.A., \& Voskuijl, O.F. (2008). A person-environment fit approach to volunteerism: Volunteer personality fit and culture fit as predictors of affective outcomes. Basic and Applied Social Psychology, 30(2), 153-166.

Vecina, M., Chacon, F., Marzana, D., \& Marta, E. (2013). Volunteer engagement and organizational commitment in nonprofit organizations: What makes volunteers remain within organizations and feel happy? Journal of Community Psychology, 41(3), 291-302.

Wallace, H.M., \& Tice, D.M. (2012). Reflected appraisal through a 21st-century looking glass. In M.R. Leary \& J. Price Tangney (Eds.), Handbook of self and identity (2nd edition) (pp. 124-140). New York, NY: The Guilford Press.

Weng, S.S., \& Lee, J.S. (2016). Why do immigrants and refugees give back to their communities and what can we learn from their civic engagement? Voluntas: International Journal of Volunteering and Nonprofit Organizations, 27(2), 509-524.

Wharton, C.S. (1991). "Why can't we be friends?" Expectations versus experiences in the volunteer Role. Journal of Contemporary Ethnography, 20(1), 79-106.

Wilson, J. (2000). Volunteering. Annual Review of Sociology, 26, 215-240.

Wilson, J. (2012). Volunteerism research: A review essay. Nonprofit and Voluntary Sector Quarterly, 41(2), $176-212$.

Wilson, J., \& Musick, M.A. (1999). Attachment to volunteering. Sociological Forum, 14(2), 243-272.

Zurcher, L.A. (1983). Social roles. Conformity, conflict and creativity. Beverly Hills, CA: Sage Publications.

\section{ABOUT THE AUTHOR / L'AUTEUR}

Behnam Behnia, PhD, is Associate Professor in the School of Social Work, Carleton University, 1125 Colonel By Drive Ottawa, ON. K1S 5B6, Email: behnambehnia@cunet.carleton.ca 